\title{
High-efficient microwave-assisted method for the preparation of foamed liquid glass granules
}

\author{
T.E.Rimar ${ }^{1}$, E.Ju.Kryuchkova ${ }^{1}$, N.A.Pinchukova ${ }^{2}$, A.Y.Voloshko $^{2}$, \\ V.A.Chebanov ${ }^{2,3}$ \\ ${ }^{1}$ Severodonetsk Technology Institute of V. Dahl East Ukrainian National \\ University, 59-a Radyanskiy Ave., 93400 Severodonetsk, Ukraine \\ ${ }^{2}$ SSI "Institute for Single Crystals", National Academy of Sciences of \\ Ukraine, 60 Nauky Ave., 61072 Kharkiv, Ukraine \\ ${ }^{3}$ V.Karazin Kharkiv National University, \\ 4 Svobody Sq., 61022 Kharkiv, Ukraine
}

\section{Received February 2, 2016}

In the present work, feasibility and efficiency of microwave-assisted preparation of the foam glass granules intended for production of the blocked heat-insulating materials were studied, and the effect of MW irradiation on the quality of the prepared foamed granules was assessed. The high quality material was obtained using microwave irradiation at much lower temperature in comparison with the known thermal method. The optimal process parameters were properly elaborated and analyzed.

Keywords: heat-insulation materials, liquid glass, granules foaming, microwave irradiation, energy efficiency.

Исследованы реализуемость и эффективность микроволнового метода получения вспененных гранул на основе жидкого стекла, используемых в производстве блоковых теплоизоляционных материалов, оценивается влияние параметров микроволнового процесса на качество полученных гранул. В результате применения микроволнового излучения получен высококачественный гранулированный пеноматериал при гораздо более низкой температуре в сравнении с известным термическим методом. Определены оптимальные параметры микроволнового процесса вспенивания.

Високоефективний мікрохвильовий метод виготовлення спіненого теплоізолюючого гранульованого матеріалу на основі рідкого скла. T.E. Рนлар, К.Ю. Крючкова, Н.O. Пінчукова, О.Ю. Волошко, В.А. Чебанов.

Вивчено реалізованість та ефективність мікрохвильового методу виготовлення спінених гранул на основі рідкого скла, що використовуються для виробництва блокових теплоізолюючих матеріалів, оцінюється вплив мікрохвильового випромінювання на якість отриманих гранул. В результаті використання мікрохвильового поля отримано високоякісний гранульований піноматеріал при значно нижчій температурі у порівнянні з відомим термічним методом. Визначено оптимальні параметри процесу мікрохвильового спінення.

\section{Introduction}

Development of the energy-saving building technologies is nowadays a very topical issue. The growing demand for reduction of walling costs and multi-stored buildings weight, as well as the rigid requirements to the heat-insulation characteristics of the outer walls stimulates the development and introduction into the market of effective heat-insulating materials, e.g. foamed polystyrene, light gas concrete, etc. [1]. How- 
ever, mineral-based materials with synthetic binders, polystyrene and other organic materials, are known to be nondurable since they lose their heat-insulating properties with time [2].

In this respect the foam glasses appear to be a good alternative to the existing insulators, being non-combustible light weight materials. Today, the granular foam glass insulators are gaining acceptance all over the world due to their versatility, since they can be used either as bulk insulation, or as fillers in production of the block elements. The main benefit of the foam glass materials is their uniform pore structure providing low heat conductivity. The closed pore structure and existence of inter-granular voids, being the pores of irregular form, determine their good heat-insulation properties along with the consistency of performance in general [3]. All these factors are the evidence of high potential of the granular heat-insulating materials for the development of up-to-date building technologies [1, $4]$.

Generally, the foam glass materials are prepared by addition to the liquid glass of mineral fillers and foaming agents and foaming at temperatures above the point of softening (usually above $500^{\circ} \mathrm{C}$ ) $[1,4]$ which makes this method the energy intensive technology. The average bulk density of the foam glasses varies from 120 to $300 \mathrm{~kg} / \mathrm{m}^{3}$.

One of the feedstock materials used for the foam glass preparation is cheap and environmentally friendly liquid or water glass. By the nature of foaming techniques, all liquid glass materials may be divided into the thermally foamed ones and those obtained in result of chemical reaction between the liquid glass and special foaming additives. Granular and calcinated monolith materials are representatives of the thermally foamed ones. In this case the included water can act as a foaming agent due to its vaporization during heating process, thus supporting pores formation [4].

In order to obtain the best quality of the insulating material, i.e. low density, high mechanical strength etc., the rheological characteristics of the incoming liquid glass composition should be regulated by the addition of finely ground mineral substances acting as the filling aggregates. There is a great number of materials used as such fillers, e.g. chalk (calcium carbonate), sand, talc, kaolin, alumina, asbestos dust etc.[5].
The glass foaming may be performed using either conventional (thermal) or microwave (dielectric) heating. The conventional heating is characterized by high energy consumption, considerable process times, insufficient heating of the inner layers and, as a result, by the poor quality of the materials. In contrast, (microwave) MW irradiation has the ability to penetrate inside the material and to heat the whole volume simultaneously [6,7]. Therefore, this method showed the high-efficiency for carrying out both laboratorial scale and industrial-oriented chemical and physicochemical processes [8-10].

Due to rapid vaporization of water contained within granules, causing pores formation, MW foaming seems to be more effective comparing with the thermal heating where vaporization speed greatly depends on granules heat conductivity. Dedicated MW equipment allows precise temperature and pressure control and fine power tuning, and provides homogeneous electric field inside MW cavity. Moreover, incorporated mixing devices improving mass and heat transfer, and rapid cooling systems provided with the most of commercial MW reactors allow very accurate control of heating time and guarantee high reproducibility of the results.

The main goal of the present work is to study influence of MW irradiation on foaming behavior of the liquid glass and on heat insulation properties of the foamed granules. The optimal MW parameters of the granules foaming were established allowing effective removal of all the moisture contained within the granules, and attaining the high foaming factors and low density of the target materials.

\section{Experimental procedure}

Materials and granules preparation procedure

For preparation of liquid glass granules the following materials were used:

1) liquid glass contained $\mathrm{SiO}_{2}-29.7 \%$, $\mathrm{Na}_{2} \mathrm{O}-10.6 \%$; silica modulus 3.05 ; water and impurities - $59.7 \%$ density $1.4 \mathrm{~g} / \mathrm{cm}^{3}$,

2) finely ground $\mathrm{ZnO}$ - colorless nonsoluble in water crystalline powder, growing yellow under heating, assay (on $\mathrm{ZnO}$ basis) - no less than 99.7 wt. \% .

Prior to the study a number of substances were tested in order to select the most appropriate filling aggregate for the liquid glass composition, which were kaolin, 
calcium carbonate, dolomite powder, zinc oxide and ferric oxide. Zinc oxide was finally selected, because it showed the best results out of the studied substances ceteris paribus with respect to rheological properties of the liquid glass composition and the final granules quality, i.e. the lowest density, as well as the lowest sorption humidity and water absorption (14.6 and 26.4 per cent, respectively) of the granules were obtained. Such benefits provided by use of $\mathrm{ZnO}$ are explained by its good gel-forming properties. It is known that gelling increases viscosity of the liquid glass composition, thus facilitating further granulation. However, excess of the mineral filler is undesirable because it may cause the breakdown of the liquid glass polymeric structure, accompanied by the transition of some part of the bound water into free one, resulting in poor pore formation during the liquid glass foaming. Thus, the filling aggregates should be dosed with care in order to avoid product quality loss. On the basis of the viscosity measurements the optimal liquid glass: zinc oxide weight ratio was found to be 100:1.5.

Procedure applied for preparation of the granulated foam glass consisted of the following steps [11]:

1) Preparation of mixture of liquid glass and appropriate additives;

2) partial dehydration of the mixture obtained;

3) mixture granulation;

4) granules foaming.

Liquid glass mixture was prepared by thorough mixing of the liquid glass and mineral additives. The homogeneous mixture was then transferred in haphazard manner into a bath filled with calcium chloride solution $(\rho=1.29-1.35 \mathrm{~g} / \mathrm{mL})$, where the drops of the mixture turn into granules (beads) with the hardened upper layer being the silica gel with adsorbed calcium oxide. The optimal residence time for the granules to form the solid upper layer was found to be $40 \mathrm{~min}$ at temperature of $22-30^{\circ} \mathrm{C}$. Then the calcium chloride solution was decanted, and the obtained granules were dried at the room temperature in the open air. The dry granules were then subjected to foaming in the MW field.

Granules foaming experiments

MW-mediated foaming experiments were performed with the use of home-made MW equipment, designed and manufactured at SSI "Institute for Single Crystals" of NAS of Ukraine (Fig. 1).

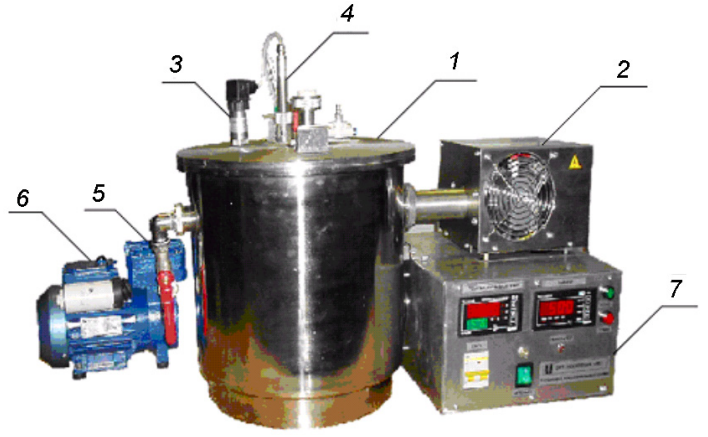

Fig. 1. Photo of lab-scale MW equipment used in the granules foaming experiments: 1Multimode MW cavity (dimensions: $h=$ $35 \mathrm{~cm}, d=30 \mathrm{~cm}$ ); 2 - MW generator (output power - $1.0 \mathrm{~kW}$, operated frequency $2450 \mathrm{MHz}$; 3 - IR pyrometer for temperature measurements $\left(-20-200^{\circ} \mathrm{C}\right)$, accuracy $\left.\pm 0.5^{\circ} \mathrm{C}\right) ; 4$ - pressure sensor $(0-100 \mathrm{kPa})$, accuracy $\pm 0.2 \mathrm{kPa}$ ); 5 - vacuum tract; 6 - vacuum pump; 7 - control unit.

To carry out the MW experiments the sample granules (about $40 \mathrm{~g}$ ) were loaded into special plastic radio-transparent vessel. Dehydration degree of the samples was determined on the weight loss basis.

Density measurements

Sample density was determined as per [12] by the following procedure. Prior to weighing the sample was cooled in the desiccator at the room temperature $\left(m_{1}\right)$.Then the sample was saturated by keeping it under the saturation liquid (water) for $4 \mathrm{~h}$, and the hydrostatic weighing of the sample was performed $\left(m_{2}\right)$. Then the sample was separated from water, the excess of liquid was removed from the granules surface by a sponge or cotton cloth wetted with the saturation liquid; and the sampled was weighed $\left(m_{3}\right)$. The apparent density of the material was estimated by the formula:

$$
\rho_{\text {app }}=\frac{m_{1}}{m_{3}-m_{2}} \cdot \rho_{l}, \mathrm{~g} / \mathrm{cm}^{3},
$$

where $m_{1}$ is weight of the dry sample, g; $m_{2}$ is weight of the sample immersed into liquid, g; $m_{3}$ is weight of the saturated sample, $g ; \rho_{l}$ is density of the saturation liquid at the experimental temperature, $\mathrm{g} / \mathrm{cm}^{3}$.

Loss on drying determination

The loss on drying was estimated similar to the estimation of the absolute moisture content for heat insulation materials according to [13]. Granulated materials are weighed and dried to the constant weight in a drying chamber at $50-60^{\circ} \mathrm{C}$. Prior to the 
Table. Process parameters in the liquid glass foaming experiments and characteristics of the foamed glass obtained under different operation conditions

\begin{tabular}{|c|c|c|c|c|c|c||}
\hline $\begin{array}{c}\text { Run } \\
\text { Number }\end{array}$ & $\begin{array}{c}\text { MW power, } \\
\text { W }\end{array}$ & $\begin{array}{c}\text { Operation } \\
\text { pressure, kPa }\end{array}$ & $\begin{array}{c}\text { Maximal } \\
\text { temperature, }{ }^{\circ} \mathrm{C}\end{array}$ & Weight loss, \% & $\begin{array}{c}\text { Sample } \\
\text { density, g/cm }{ }^{3}\end{array}$ & $\begin{array}{c}\text { Foaming } \\
\text { coefficient }\end{array}$ \\
\hline 1 & 300 & 99.5 & 53 & 3.8 & 0.68 & 1 \\
2 & 500 & 95 & 108 & 24.2 & 0.332 & 2.4 \\
3 & 500 & 9.5 & 104.7 & 23.5 & 0.45 & 1.3 \\
4 & 650 & 9 & 75.6 & 27.5 & 0.26 & 1.97 \\
5 & 650 & 99.5 & 118 & 31.75 & 0.23 & 2.5 \\
\hline \hline
\end{tabular}

repeat weighing, the samples were kept above the mixture of calcium chloride and sulfuric acid $\left(1.84 \mathrm{~g} / \mathrm{cm}^{3}\right)$ until the room temperature was reached. The moisture content was calculated by the formula:

$$
W=\frac{m-m_{1}}{m_{1}} \cdot 100,
$$

where $W$ is moisture content in the foamed material, $\%$; $m$ is weight of the sample before drying, $\mathrm{g} ; m_{1}$ is weight of the dried sample, g.

\section{Results and discussion}

The first experiments on the granules foaming were performed at the average MW power of $300 \mathrm{~W}$ under atmospheric pressure (Run 1). The process duration was 5 min allowing achieving the constant sample volume and weight. Under these conditions the sample temperature reached in the experiment was only $53^{\circ} \mathrm{C}$ and the weight loss was as little as $3.8 \%$. It indicates that only the surface moisture was removed, while for the effective foaming the temperature level not less than $100^{\circ} \mathrm{C}$ are generally required, i.e. when the surface water is removed and the bound water starts to vaporize. It should be noted here that in the MW experiments only the surface temperature was recorded by means of IR sensors, while the temperature inside the granules could be higher. Nevertheless, the sample density in Run 1 was too high (Table) confirming that the applied MW power was not enough. Therefore, further experiments were carried out at the higher MW powers.

At $500 \mathrm{~W}$ under atmospheric conditions (Fig. 2, run 2, curve 1) the sample temperature after $5 \mathrm{~min}$ of $\mathrm{MW}$ irradiation reached its maximal value of $108^{\circ} \mathrm{C}$ and remained the same over the rest of the run. As a result, strong granules agglom-



Fig. 2. Thermograms of the foaming experiments conducted at $500 \mathrm{~W}: 1$ - under atmospheric pressure; 2 - under vacuum conditions.



Fig. 3. Thermograms of the foaming processes conducted at $650 \mathrm{~W}: 1$ - under vacuum conditions; 2 - under atmospheric conditions.

eration was observed which was obviously caused by the water condensation and resorption on the granules surface; for this reason the sample density was high (Table).

Therefore, to prevent the water condensation, further experiments were carried out under vacuum conditions (pressure $9.5 \mathrm{kPa}$ ) at $\mathrm{MW}$ power of 500 and $650 \mathrm{~W}$ (Table, runs 3 and 4 , respectively). 

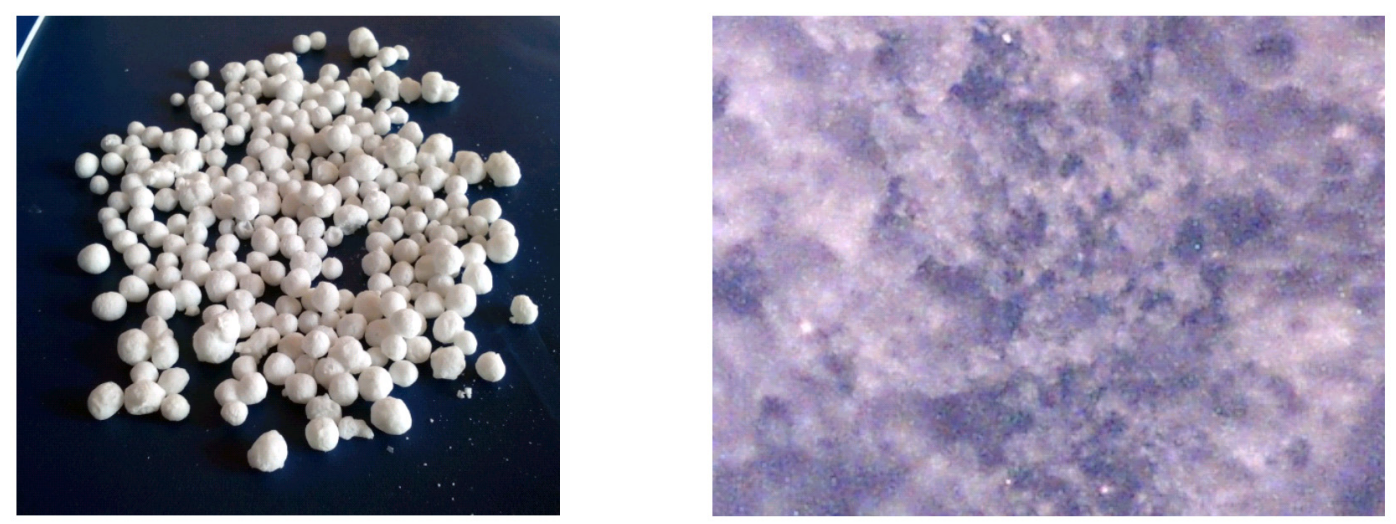

Fig. 4. Photo of the foamed granules obtained under optimal microwave conditions (left) and microphotograph (60-fold magnification) of the cross-section of the foamed granule (right).

Curve 2 (Fig. 2) shows that rapid temperature growth was observed in Run 3 , and the maximal temperature of $104.7^{\circ} \mathrm{C}$ was reached. However, after 3 min of MW irradiation the gradual temperature lowering started, and by the end of the Run it fell to $60^{\circ} \mathrm{C}$. Such temperature drop indicated that all the moisture was removed from the sample, and no water was left to absorb microwaves. The sample analysis revealed that in spite of the fact that the weight loss in Run 3 was commensurable with that in Run 2, the foaming coefficient was much lower (Table). The sample density was $450 \mathrm{~kg} / \mathrm{m}^{3}$, which was too high for the foamed materials. The poor quality of the granules obtained in Run 3 can be explained by too fast water evaporation. Indeed, it is known, that the foaming phenomenon is based on the rapid water vaporization resulting in high pressure inside the granules. High pressure gradients cause structural changes in the granules, being the driving force of the granules foaming and pores formation. If water evaporates too fast, the pressure inside the granules generated by the residual water is not enough to cause the effective foaming.

Better results were obtained in Run 4 which carried out at MW power of 650 and more accurate pressure control. Though the temperature was much lower than in Run 3 because of low pressure (Fig. 3, curve 1), the separate foamed granules with much lower density were obtained (Table), and no cohesion was observed. However, the weight loss at the level of $27.5 \%$ indicated that the bound water was not totally removed. Evidently, it can be explained by the fact that the sample temperature was too low to generate the necessary pressure inside the granules, enough for the efficient pore formation.

To ensure the higher temperatures the higher pressures have to be applied. However, water condensation should be prevented, therefore, the next experiment (Table, run 6) was carried out at the pressure close to the atmospheric one $(98 \mathrm{kPa})$, and slight air purge was provided for removal of the water vapor.

The maximal temperature achieved in this run was high enough $\left(118^{\circ} \mathrm{C}\right)$ (Fig. 3, curve 2 ), resulting in the high weight loss, which means that both free and bound water was removed. The sample density of the foamed sample achieved under the applied conditions was $230 \mathrm{~kg} / \mathrm{cm}^{3}$, which was the lowest among all the runs, and the foaming coefficient was the highest (Table). The obtained sample represented regular round-shaped granules, with no sign of agglomeration, which had the developed pore structure (Fig. 4).

Thus, it can be inferred that high MW power $(650 \mathrm{~W}$ for the given sample weight) and pressure close to the atmospheric one with air purge provided to prevent water resorption, ensure good quality of the foamed granules. The obtained low-density granules can be used as the heat insulation materials.

\section{Conclusions}

The results obtained in this study show that microwave irradiation can be effectively used for development of cost effective and energy efficient methods for preparation of the foam glass heat insulation materials.

It has been shown that the low-density foamed materials can be obtained in microwave field at relatively low temperatures $\left(118-120^{\circ} \mathrm{C}\right)$ as compared to the correspond- 
ing thermal processes (above $500^{\circ} \mathrm{C}$ ). Using microwave irradiation the high quality foam granules were prepared from the composition comprising liquid glass and zinc oxide as mineral filler. Zinc oxide was selected among a number of other mineral materials due to its best gel-forming performance allowing achieving the optimal viscosity of the liquid glass.

It has been shown that the lowest granules density is obtained under the pressure close to the atmospheric one, meanwhile vacuum conditions are inapplicable for the process because of the low temperature of the material, which together with too fast water removal results in poor pores formation. However, measures must be taken to prevent water condensation and resorption by the granules, which may cause the granules slump and result in the high density of the final material. To prevent the water condensation the slight underpressure $(98 \pm 1 \mathrm{kPa})$ along with air purge may be applied.

The microwave-assisted preparation of the liquid glass granules can obviously be successfully scaled up due to good absorbance of the granules, for which purpose the tailored equipment should be designed. However, this is the aim of our further investigations.

\section{References}

1. A.Ayadi, N.Stiti, K.Boumchedd et al., Powder Technology, 208, 423 (2011).

2. K.S.Ivanov, Kriosphera Zemli, XV, 120 (2011).

3. M.Yu.Ivanov, Sistemy, Metody, Tehnologii, 2 102 (2014).

4. D.Hesky, C.G.Aneziris, U.Gro $\beta$, A.Horn, $C e^{-}$ ramics Intern., 41, 12604 (2015).

5. A.I.Kudyakov, N.A.Svergunova, M.Yu.Ivanov, Granular Heat Insulation Material Based on the Modified Liquid Glass Composition, Tomsk State University of Architecture and Construction, Tomsk (2010) [in Russian].

6. J.M.R. Belanger, J.R.J. Pare, O. Poon et al., Remarks on various applications of microwave energy, Journal of Microwave Power \& Electromagnetic Energy, 42 (4), 24 (2008).

7. A.Loupy, Microwaves in Organic Synthesis, 2nd ed., Wiley-VCH, Weinheim (2006).

8. N.A.Pinchukova, A.Y.Voloshko, O.V.Shyshkin et al., Org. Process Res. Dev., 14, 1130 (2010).

9. N.A.Pinchukova, V.A.Chebanov, N.Y.Gorobets et al., Chem. Eng. Process., 50, 1193 (2011).

10. R.Hoogenboom, T.F.A.Wilms, U.S.Schubert, Polym. Preprints (Am.Chem.Soc., Div.Polym. Chem.), 49, 930 (2008).

11. http://www.studfiles.ru/preview/430904/, Foamed Liquid Glass Materials [in Russian]..

12. State Standard 2409-95. Refractories. Methods for Determination of Bulk Density, Apparent and True Porosity, Water Absorption [in Russian].

13. State Standard 17177-94. Building Heat Insulating Materials and Elements [in Russian]. 